\title{
Optimum Plot Size and Number of Replications for Determining Watermelon Yield, Fruit Size, Fruit Firmness, and Soluble Solids
}

\author{
George E. Boyhan ${ }^{1}$ \\ University of Georgia, Department of Horticulture, 1111 Miller Plant Science \\ Building, Athens, GA 30602
}

Additional index words. cucurbits, Citrullus lanatus, Cucurbitaceae, variety evaluation

\begin{abstract}
Plot size and number of replications were evaluated for watermelon [Citrullus lanatus (Thunb.)] over a 3-year period. Four different methods were used, including plotting basic unit plots against changes in cvs, Hatheway's method for detecting a true difference as a percent of the mean with a $20 \%$ threshold, Bartlett's homogeneity of variance test, and computed least significant differences (LSDS). An initial evaluation was done in a trial with several varieties. Plotting $\mathrm{CV}$ against number of basic units using plots with different watermelon varieties suggests a plot size of $\approx 7$ basic units ( 1 basic unit $=$ $3.34 \mathrm{~m}^{2}$ ). With a single variety and basic units of $6.69 \mathrm{~m}^{2}$ for inside rows, the plot size was $\approx 4$ basic units and for the outside row 5 basic units. With plot sizes of $2.23 \mathrm{~m}^{2}$, the number of basic units per plot was estimated at $\approx 5$ basic units. Bartlett's test suggests larger basic unit plot sizes of 14 to 20 with a $3.34-\mathrm{m}^{2}$ basic unit size with multiple varieties. With a single variety, 4 to 8 basic unit plot sizes are required with $6.69-\mathrm{m}^{2}$ basic unit size. Results were unreliable with $2.23-\mathrm{m}^{2}$ plot sizes using Bartlett's test. Computed LSDs, which were $5 \%$ of the mean or less, could be achieved with plots sizes of 10 basic units and five replications with $3.34-\mathrm{m}^{2}$ basic unit plots and using multiple varieties. Other combinations meeting these criteria included 14 basic unit plots and two or three replications. With a $6.69-\mathrm{m}^{2}$ basic unit size, plots of 6 basic units and four replications would meet the $5 \%$ criteria. Finally, with the $2.23-\mathrm{m}^{2}$ basic unit size, a plot size of 8 basic units and three replications would result in an LSD of 5\% of the mean. Results with Hatheway's method were similar to plots of basic units against $\mathrm{CV}$. Hatheway's method also has an estimate of number of replications and with $3.34-\mathrm{m}^{2}$ basic unit, the $20 \%$ threshold of detecting true differences occurred with 10 to 14 basic units and four replications. For fruit size, firmness, and soluble solids, the basic unit plot sizes ranged from 5 to 7 . Plot size estimates were larger with $6.69 \mathrm{~m}^{2}$ compared with $2.23 \mathrm{~m}^{2}$ for fruit characteristics.
\end{abstract}

Watermelons [Citrullus lanatus (Thunb.)] are an important crop in the United States with over 132,000 acres harvested with a value of \$492 million (USDA, 2011). There are many varieties available and seed companies continue to develop new ones. As new varieties are introduced to the market, growers, seed companies, and extension personnel are interested in how well they will perform. Consequently, there is an ongoing need for varietal evaluations. Optimum plot size, shape, and number of replications have been studied in a number of crops such as sweetpotatoes [Ipomoea batatas (L.) Lam.], onions (Allium cepa L.), peppers (Capsicum annum L.), and potatoes (Solanum tuberosum L.) to name a few (Boyhan et al., 2003; Lana et al., 1953; Singh, 1989; Vallejo and Mendoza, 1992).

Locascio et al. (1966) found a sharp reduction in the watermelon yield $\mathrm{CV}$ from oneplant plots $(40 \%)$ to nine-plant plots $(11 \%)$. The reduction in CV was less with mean fruit

Received for publication 4 Feb. 2013. Accepted for publication 2 July 2013.

${ }^{1}$ To whom reprint requests should be addressed; e-mailgboyhan@uga.edu. weight and there were no consistent differences between different locations. A survey of watermelon plant breeders and their variety evaluation methods indicated that private breeders use more plants per plot but have fewer replications compared with public breeders (Neppl and Wehner, 2001).

Other crops have been evaluated for optimum plot size, plot shape, and number of replications. In a study of corn (Zea mays L.), an optimum plot size consisting of four to five rows was considered better than three-row plots. In addition, there was a significant variety-by-plot size interaction effect with late corn varieties in a simulated split-plot design but no such interactions with early varieties (Pecina, 1993). In an experiment with mustard [Brassica juncea (L.) Czern.], the optimum plot size and number of replications was $7.2 \mathrm{~m}^{2}$ and four, respectively (Bhatnagar et al., 1991). In a study in Sri Lanka with potatoes, the latin square design had the greatest precision on heterogenous soils with an optimum plot size of 25 to $40 \mathrm{~m}^{2}$ (Pemajayantha and Gunasekara, 1982). Finally, Parlak and Kircalioglu (1979) in evaluations of tomatoes (S. lycopersicum L.), peppers, and eggplants ( $S$. melongena L.) found optimum plot sizes of 24 to $36 \mathrm{~m}^{2}$ for tomatoes and $35 \mathrm{~m}^{2}$ for peppers and eggplants for replicated experiments. In each case, the optimum number of replications was five.

It is advantageous to know the optimum plot size and number of replications to conserve resources while obtaining the necessary information to confidently draw conclusions from a study. Therefore, the objective of this study was to determine the optimum plot size and number of replications necessary to detect differences in yield, fruit size, fruit firmness, and soluble solids.

\section{Materials and Methods}

Watermelon plants were grown at the Vidalia Onion and Vegetable Research Center in Lyons, GA (lat. $32^{\circ} 11^{\prime} \mathrm{N}$, long. $82^{\circ} 17^{\prime} \mathrm{W}$ ). In 2006, plots measured were the inside (watermelons planted on either side of the plot) and border rows (watermelon plants on only one side of the plot) from a variety trial that consisted of 22 entries with the majority (19) of the entries triploids. Two of the triploid entries were mini-watermelons, 'Precious Petite' and 'Little Deuce Coupe'. The non-triploid entries were hybrid varieties. In 2007 and 2008, only 'Jamboree' watermelon was used. All watermelons were grown according to University of Georgia Cooperative Extension Service recommendations (Boyhan and Kelley, 2000). Plants were spaced with an in-row and betweenrow spacing of $1.83 \mathrm{~m}$. Data were collected from an inside row (watermelon plants on either side) as well as an outside or border row with watermelons only on one side of the plots.

Three-week-old plants were transplanted on 22 May 2006, 30 May 2007, and 10 Apr. 2008. Fruit were harvested on 20 July 2006, 8 Aug. 2007, and 2 July 2008 and the weight per plot or basic unit was recorded. Rows were divided into plots of $1.83,3.66$, and $1.22 \mathrm{~m}$ in length in 2006, 2007, and 2008, respectively. All plots had the same width of $1.83 \mathrm{~m}$. This resulted in plot sizes of $3.34 \mathrm{~m}^{2}, 6.69 \mathrm{~m}^{2}$, and $2.23 \mathrm{~m}^{2}$ for 2006,2007 , and 2008, respectively, which were the basic units in each year of the study. The total number of basic units must be divisible by the chosen plot sizes without a remainder (Gomez and Gomez, 1984). In 2006, 140 basic unit plots of inside and border rows were harvested, which results in 12 different plot sizes for evaluation. In 2007, there were 36 basic unit inside plots and 80 border row plots harvested. Because the number of basic units is chosen to maximize the number of plot sizes that can be divided evenly into the maximum number of basic units, in 2007, 36 inside basic units were chosen because nine different plot sizes could be evaluated, whereas with 40 basic units, only seven different plot sizes could be evaluated. For border rows with 80 basic units, 10 different plot sizes could be evaluated. Finally, in 2008 , there were 64 inside and border row plots harvested, which had seven different plot sizes that met the criteria for evaluation.

In addition to yield, data on fruit size, soluble solids, and fruit firmness were collected in 2007 and 2008. These data were collected on a single fruit from each basic unit plot. 


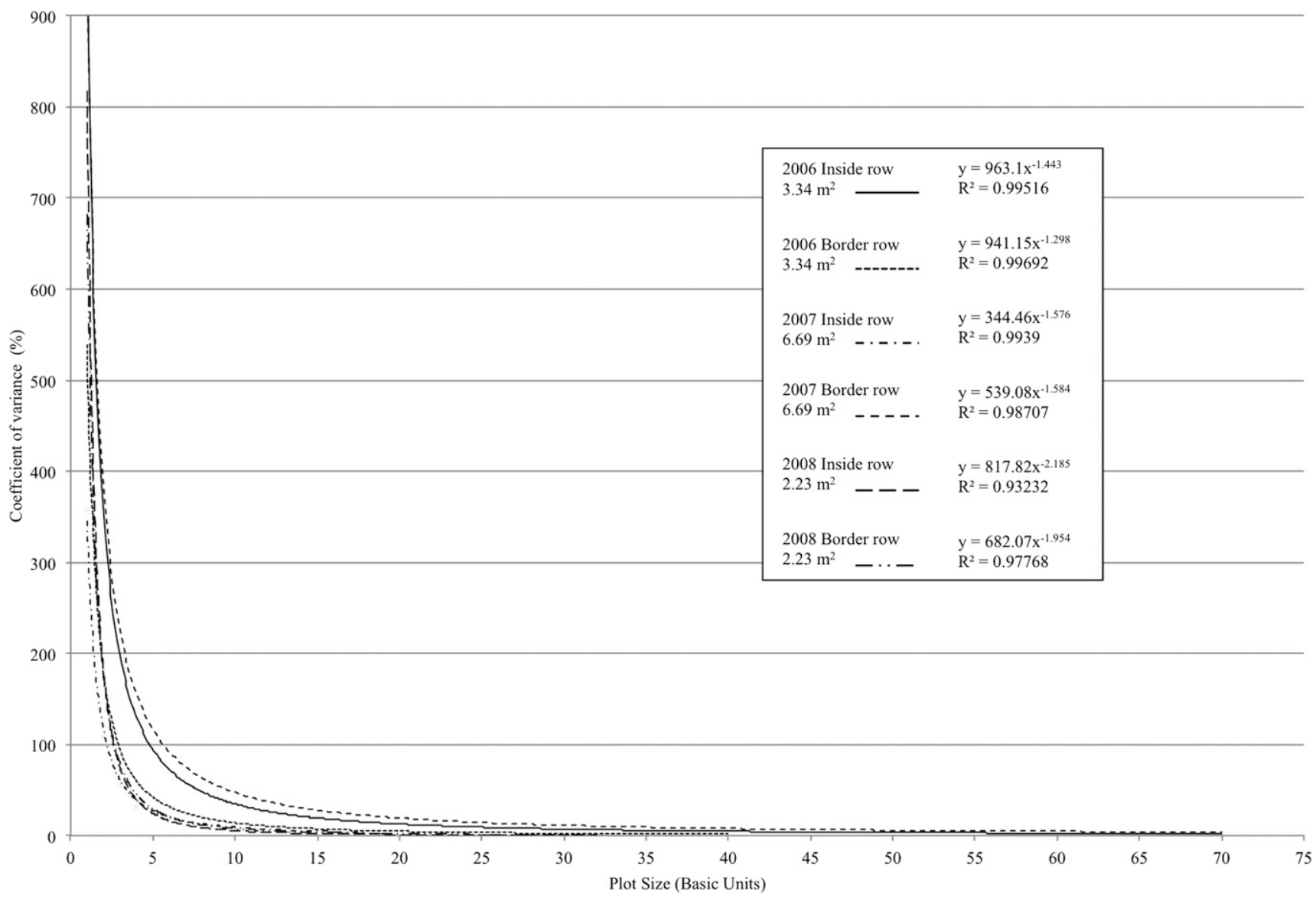

Fig. 1. Power trendlines of $\mathrm{cv}$ against plot sizes for yield with basic unit plot sizes of $3.34 \mathrm{~m}^{2}$ for $2006,6.69 \mathrm{~m}^{2}$ for 2007 , and $2.23 \mathrm{~m}^{2}$ for 2008 . Inside rows have watermelon plants on either side of the plot, whereas outside rows (border rows) have watermelon plots on one side only.

Table 1. Between plot variance $\left[\mathrm{V}_{(\mathrm{x})}\right]$, variance per unit area $\left(\mathrm{V}_{\mathrm{x}}\right)$, and $\mathrm{cv}$ for inside and border rows of watermelons with various basic unit plot sizes, 2006

\begin{tabular}{|c|c|c|c|c|c|}
\hline $\begin{array}{l}\text { Basic } \\
\text { units }^{z}\end{array}$ & $V_{(x)}$ & \multicolumn{2}{|l|}{$\mathrm{V}_{\mathrm{x}}$} & df & CV (\%) \\
\hline \multicolumn{6}{|c|}{ Inside row } \\
\hline 1 & 11,080 & 11,080 & $a^{y}$ & 139 & 897 \\
\hline 2 & 5,413 & 1,353 & $\mathrm{~b}$ & 69 & 314 \\
\hline 4 & 3,686 & 230.4 & $\mathrm{c}$ & 34 & 129 \\
\hline 5 & 3,160 & 126.4 & $\mathrm{c}$ & 27 & 96 \\
\hline 7 & 3,188 & 65.1 & $\mathrm{~d}$ & 19 & 69 \\
\hline 10 & 1,921 & 19.2 & e & 13 & 37 \\
\hline 14 & 1,448 & 7.39 & ef & 9 & 23 \\
\hline 20 & 964 & 2.41 & fg & 6 & 13 \\
\hline 28 & 971 & 1.24 & fg & 4 & 9 \\
\hline 35 & 348 & 0.28 & $\mathrm{~g}$ & 3 & 5 \\
\hline 70 & 228 & 0.05 & $\mathrm{~g}$ & 1 & 2 \\
\hline \multicolumn{6}{|c|}{ Border row } \\
\hline 1 & 30,002 & 30,002 & $a^{y}$ & 139 & 1002 \\
\hline 2 & 18,173 & 4,543 & $\mathrm{~b}$ & 69 & 390 \\
\hline 4 & 12,860 & 803.7 & c & 34 & 164 \\
\hline 5 & 8,611 & 344.4 & d & 27 & 107 \\
\hline 7 & 9,117 & 186.1 & $\mathrm{e}$ & 19 & 79 \\
\hline 10 & 6,595 & 65.95 & ef & 13 & 47 \\
\hline 14 & 4,418 & 22.54 & fg & 9 & 27 \\
\hline 20 & 4,005 & 10.01 & $\mathrm{~g}$ & 6 & 18 \\
\hline 28 & 2,841 & 3.62 & $\mathrm{~g}$ & 4 & 11 \\
\hline 35 & 3,150 & 2.57 & $\mathrm{~g}$ & 3 & 9 \\
\hline 70 & 3,128 & 0.64 & $\mathrm{~g}$ & 1 & 5 \\
\hline
\end{tabular}

${ }^{\mathrm{z}}$ Basic unit size $=3.34 \mathrm{~m}^{2}$.

${ }^{y}$ Separation by Bartlett's $\chi^{2}$ test for homogeneity of variance $(P \leq 0.05)$.

HortScience Vol. 48(9) September 2013
Table 2. Between plot variance $\left[\mathrm{V}_{(\mathrm{x})}\right]$, variance per unit area $\left(\mathrm{V}_{\mathrm{x}}\right)$, and $\mathrm{CV}$ for inside and border rows of watermelons with various basic unit plot sizes, 2007.

\begin{tabular}{rrclrr}
\hline $\begin{array}{c}\text { Basic } \\
\text { units }^{\mathrm{z}}\end{array}$ & $\mathrm{V}_{(\mathrm{x})}$ & \multicolumn{5}{c}{$\mathrm{V}_{\mathrm{x}}$} & & $\mathrm{df}$ & $\mathrm{CV}(\%)$ \\
\hline & \multicolumn{5}{c}{ Inside row } \\
1 & 11,469 & 11,469 & $\mathrm{a}^{\mathrm{y}}$ & 35 & 361 \\
2 & 4,438 & 1,109 & $\mathrm{~b}$ & 17 & 112 \\
3 & 2,712 & 301.4 & $\mathrm{c}$ & 11 & 59 \\
4 & 1,666 & 104.1 & $\mathrm{~cd}$ & 8 & 34 \\
6 & 1,294 & 35.95 & $\mathrm{~d}$ & 5 & 20 \\
9 & 1,367 & 16.87 & $\mathrm{~d}$ & 3 & 14 \\
12 & 636 & 4.42 & $\mathrm{~d}$ & 2 & 7 \\
18 & 288 & 0.89 & $\mathrm{~d}$ & 1 & 3 \\
& \multicolumn{5}{c}{ Border row } \\
1 & 23,149 & 23,149 & $\mathrm{a}$ & 79 & 512 \\
2 & 8,281 & 2,070 & $\mathrm{~b}$ & 39 & 153 \\
4 & 4,426 & 276.6 & $\mathrm{bc}$ & 19 & 56 \\
5 & 4,947 & 197.9 & $\mathrm{c}$ & 15 & 47 \\
8 & 2,140 & 33.43 & $\mathrm{~d}$ & 9 & 19 \\
10 & 2,181 & 21.81 & $\mathrm{~d}$ & 7 & 16 \\
16 & 1,407 & 5.50 & $\mathrm{~d}$ & 4 & 8 \\
20 & 1,346 & 3.36 & $\mathrm{~d}$ & 3 & 6 \\
40 & 144 & 0.09 & $\mathrm{~d}$ & 1 & 1 \\
\hline
\end{tabular}

${ }^{2}$ Basic unit size $=6.69 \mathrm{~m}^{2}$.

${ }^{y}$ Separation by Bartlett's $\chi^{2}$ test for homogeneity of variance $(P \leq 0.05)$.

Basic unit plots include both plots from inside and border rows. Fruit size consisted of subtracting the rind width from both the length and width and then multiplying the fruit
Table 3. Between plot variance $\left[\mathrm{V}_{(\mathrm{x})}\right]$, variance per unit area $\left(\mathrm{V}_{\mathrm{x}}\right)$, and $\mathrm{CV}$ for inside and border rows of watermelons with various basic unit plot sizes, 2008.

\begin{tabular}{cccccc}
\hline $\begin{array}{c}\text { Basic } \\
\text { units }^{\mathrm{z}}\end{array}$ & $\mathrm{V}_{(\mathrm{x})}$ & $\mathrm{V}_{\mathrm{x}}$ & & $\mathrm{df}$ & $\mathrm{CV}(\%)$ \\
\hline & & Inside row & & & \\
1 & 6764 & 6764 & $\mathrm{a}^{\mathrm{y}}$ & 63 & 462 \\
2 & 2972 & 742.9 & $\mathrm{~b}$ & 31 & 153 \\
4 & 1796 & 112.3 & $\mathrm{c}$ & 15 & 59 \\
8 & 782.6 & 12.23 & $\mathrm{~d}$ & 7 & 20 \\
16 & 110.0 & 0.43 & $\mathrm{e}$ & 3 & 4 \\
32 & 0.59 & 0.0006 & $\mathrm{f}$ & 1 & 0.1 \\
& & Border row & & & \\
1 & 4433 & 4433 & $\mathrm{a}^{\mathrm{y}}$ & 63 & 506 \\
2 & 2144 & 536.0 & $\mathrm{~b}$ & 31 & 176 \\
4 & 698.5 & 43.7 & $\mathrm{c}$ & 15 & 50 \\
8 & 353.9 & 5.53 & $\mathrm{~d}$ & 7 & 18 \\
16 & 82.2 & 0.32 & $\mathrm{e}$ & 3 & 4 \\
32 & 3.42 & 0.003 & $\mathrm{e}$ & 1 & 0.4 \\
\hline
\end{tabular}

${ }^{2}$ Basic unit size $=2.23 \mathrm{~m}^{2}$.

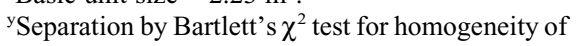
variance $(P \leq 0.05)$

length by the fruit width length $-[2 *$ rind] * [width $-(2 *$ rind $)]\}$. This resulted in a crude estimate of edible flesh. Soluble solids were measured with a $0 \%$ to $32 \%$ refractometer (Spectrum Technologies Inc., Plainfield, IL). Fruit firmness was measured with a penetrometer (Wagner Instruments, Greenwich, CT) using an 8-mm diameter probe. Two firmness 
Table 4. Computed least significant difference values and average yields based on number of replications and plot size $(P \leq 0.05$, treatment $\mathrm{df}=15)$ for watermelons, 2006.

\begin{tabular}{|c|c|c|c|c|c|c|c|c|c|c|c|}
\hline \multirow[b]{2}{*}{ No. of replications } & \multicolumn{11}{|c|}{ Plot size $z^{z}$ (no. of basic units) } \\
\hline & 1 & 2 & 4 & 5 & 7 & 10 & 14 & 20 & 28 & 35 & 70 \\
\hline 2 & 224.36 & 78.41 & 32.35 & 23.96 & 17.19 & 9.34 & 5.79 & 3.31 & 2.37 & 1.14 & 0.46 \\
\hline 4 & 149.91 & 52.39 & 21.62 & 16.01 & 11.49 & 6.24 & 3.87 & 2.21 & 1.59 & 0.76 & 0.31 \\
\hline 5 & 133.16 & 46.54 & 19.20 & 14.22 & 10.21 & $5.55^{y}$ & 3.44 & 1.96 & 1.41 & 0.67 & 0.27 \\
\hline 6 & 121.06 & 42.31 & 17.46 & 12.93 & 9.28 & 5.04 & 3.13 & 1.79 & 1.28 & 0.61 & 0.25 \\
\hline 7 & 111.78 & 39.06 & 16.12 & 11.94 & 8.57 & 4.65 & 2.89 & 1.65 & 1.18 & 0.57 & 0.23 \\
\hline & 11.7 & 23.5 & 46.9 & 58.6 & 82.1 & 117.3 & 164.2 & 234.6 & 328.4 & 410.5 & 821.0 \\
\hline & \multicolumn{11}{|c|}{ Plot size (no. of basic units) } \\
\hline & 1 & 2 & 4 & 5 & 7 & 10 & 14 & 20 & 28 & 35 & 70 \\
\hline \multicolumn{12}{|l|}{ Border row } \\
\hline 2 & 369.19 & 143.67 & 60.43 & 39.56 & 29.07 & 17.31 & 10.12 & 6.74 & 4.06 & 3.42 & 1.70 \\
\hline 3 & 288.83 & 112.40 & 47.27 & 30.95 & 22.75 & 13.54 & 7.92 & 5.28 & 3.17 & 2.67 & 1.33 \\
\hline & \multicolumn{11}{|c|}{ Avg yield per plot size $(\mathrm{kg})$} \\
\hline & 17.3 & 34.6 & 69.2 & 86.4 & 121.0 & 172.9 & 242.0 & 345.8 & 484.1 & 605.1 & 1210.2 \\
\hline
\end{tabular}

${ }^{\mathrm{z} B a s i c}$ unit plot size $=3.34 \mathrm{~m}^{2}$.

${ }^{y}$ Values in bold indicate least significant difference values $5 \%$ or less of the average plot yield.

Table 5. Computed least significant difference values and average yields based on number of replications and plot size $(P \leq 0.05$, treatment $\mathrm{df}=15)$ for watermelons, 2007.

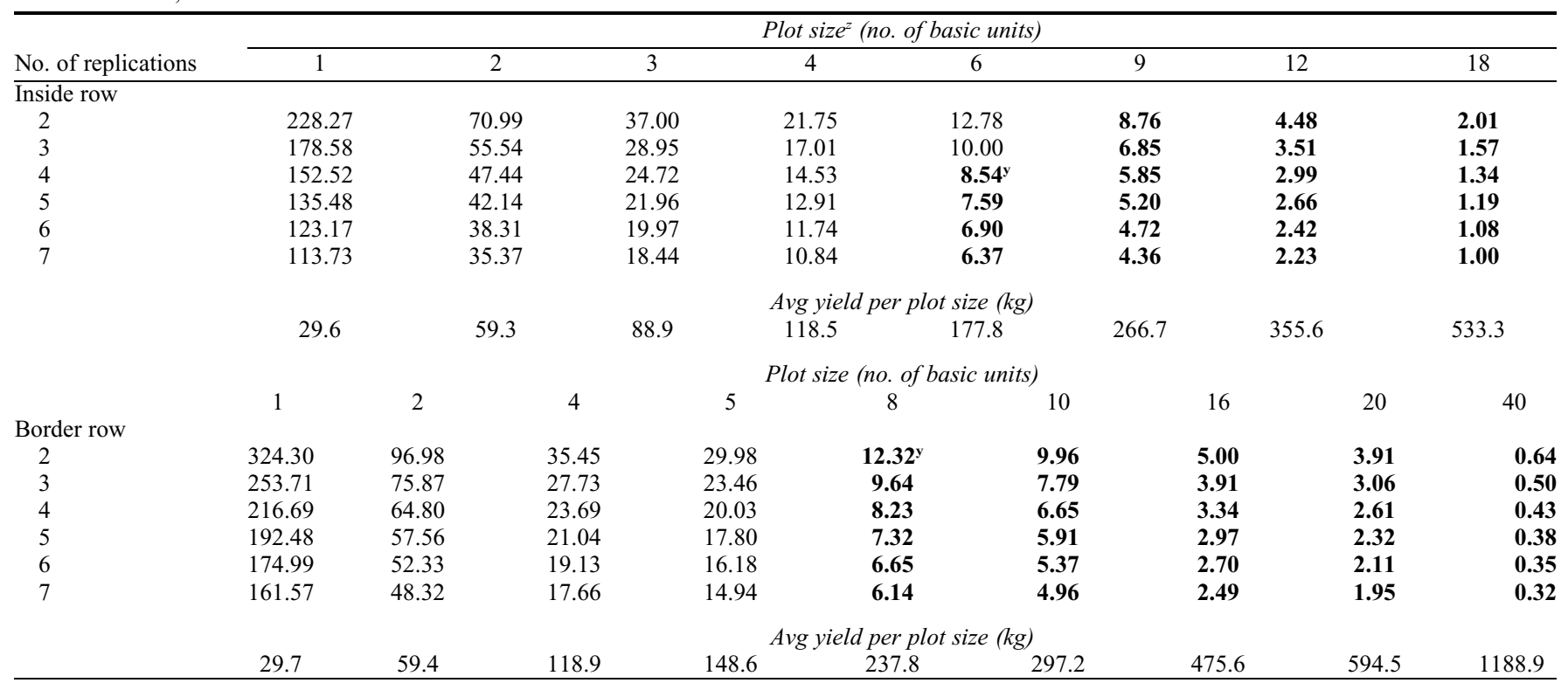

${ }^{2}$ Basic unit plot size $=6.69 \mathrm{~m}^{2}$.

${ }^{y}$ Values in bold indicate least significant difference values $5 \%$ or less of the average plot yield.

measurements were taken in the flesh of a cut watermelon and the numbers averaged.

Between plot variances, variances per unit area, CV, and Smith's adjusted index of soil heterogeneity for each year were calculated (Gomez and Gomez, 1984). Bartlett's $\chi^{2}$ test for homogeneity of variance was calculated for all possible comparisons of per-unit area variances (Gomez and Gomez, 1984).

Least significant differences were calculated for different plot sizes and replications using $15 \mathrm{df}$ for treatments and $P \leq 0.05$ (Rampton and Petersen, 1962).

Hatheway's method, which is an estimate of true differences as a percent of the mean, was estimated by the formula: $d^{2}=2\left(t_{1}+\right.$ $\left.\mathrm{t}_{2}\right)^{2} \mathrm{C}^{2}{ }_{1} / \mathrm{rx}^{\mathrm{b}}$, where $\mathrm{d}$ is the true difference between two treatments as a percent of the mean, $\mathrm{t}_{1}$ is the significant value of $\mathrm{t}$ at $0.05 P, \mathrm{t}_{2}$ is the value of $t$ corresponding to $2(1-\mathrm{P})$ where $\mathrm{P}$ is the probability of obtaining a significant result ( $80 \%$ in this case), $\mathrm{C}^{2}$ is the square of the $\mathrm{CV}, \mathrm{r}$ is the number of replications, $\mathrm{x}$ is the plot size in basic units, and b is Smith's adjusted index for soil heterogeneity (Gomez and Gomez, 1984; Hatheway, 1961). All data were analyzed with Microsoft Excel Version 14.2.4 (Microsoft Inc., Redmond, WA) on an Apple Macintosh computer (Apple Inc., Cupertino, CA).

\section{Results and Discussion}

Maximum curvature of the power trendlines was similar for yield across all years and whether the plots were inside plots or border rows (Fig. 1). The calculated maximum curvatures occurred at 6.8 for the inside row in 2006. For the border row in 2006 , the maximum curvature occurred at 6.9. The inside row with $6.69-\mathrm{m}^{2}$ plots had maximum curvature at 3.6 basic units and for the border row, it was 5.1 basic units. Finally, with $2.23-\mathrm{m}^{2}$ plots, the maximum curvature occurred at 4.5 basic units for both the inside and border rows. In 2006, 
there were 22 different varieties used, whereas in 2007 and 2008, there was only one variety, 'Jamboree'.

In 2006, with yield data, Bartlett's $\chi^{2}$ for homogeneity of variance for the inside row indicated no significant variance differences between plots of 20 basic units and 70 basic units (Table 1). There were differences between plot sizes of 1 and 2 basic units, between 2 and 4 basic units, and between 4 and 7 basic units. For the border row, there were differences between plot sizes of 1 and 2, 2 and 4, 4 and 5, and 5 and 7 basic units. Plot size of 14 basic units did not differ from 10 basic unit plot sizes. Finally, there were no significant variance differences between plots of 14 basic units and 70 basic units.

In 2007, the yield data variances for the inside row with 4 basic units did not differ from the 18 basic unit plot size (Table 2). There were variance differences, however, between 1 and 2, 2 and 3, and 3 and 6 basic unit plot sizes. With the border rows, there were no differences between 8 and 40 basic unit plot sizes. There were differences between 1 and 2 as well as 2 and 5 and 5 and 8 basic unit plot sizes.

In 2008, there were differences between all plot sizes for the inside row (Table 3). For the border row, there were differences between all plot sizes with the exception of 16 and 32 basic unit plot sizes where there were no differences.

The calculated LSD values in 2006 indicated that plot sizes of 10 basic units and five replications would result in values $5 \%$ or less of the average mean for that plot size (Table 4). This results in 50 basic units per entry. In addition, plot sizes of 14 basic units and two replications ( 28 basic units per entry) or 14 basic units and three replications (42 basic units per entry) would also result in LSD values of $5 \%$ or less of the mean for that plot size. Finally, a plot size of 20 basic units and two replications would also meet the requirement of an LSD that is $5 \%$ or less of the mean.

For the border row, the smallest plot size is 10 basic units that meets this requirement but would require seven replications (Table 4). Plot sizes of $14,20,28,35$, or 70 basic units and any number of replications of two or more would also meet these criteria.

In 2007 when the basic unit plot size was $6.69 \mathrm{~m}^{2}$, a plot size of 6 basic units and four replications would result in a calculated LSD of $5 \%$ or less of the mean for the inside row (Table 5). Other plot sizes that would meet this criteria include 9,12 , and 18 basic unit plots sizes with replications of two or greater. For the border row in 2007, plot sizes with 8 , $10,16,20$, and 40 basic units regardless of the number of replications would meet the criteria of the LSD being $5 \%$ or less of the mean.

In 2008 , the basic unit was $2.23 \mathrm{~m}^{2}$ and plot sizes of 8 basic units and three replications would result in LSD values $5 \%$ or less of the mean (Table 6). Plot sizes of 16 and 32 basic units with two to seven replications would also meet these criteria. Lastly with the border row in 2008 , plot sizes of 8,16 , and 32 basic units with replications of two to

Table 6. Computed least significant difference values and average yields based on number of replications and plot size $(P \leq 0.05$, treatment $\mathrm{df}=15)$ for watermelons, 2008 .

\begin{tabular}{|c|c|c|c|c|c|c|}
\hline \multirow[b]{2}{*}{ No. of replications } & \multicolumn{6}{|c|}{ Plot size $^{z}$ (no. of basic units) } \\
\hline & 1 & 2 & 4 & 8 & 16 & 32 \\
\hline \multicolumn{7}{|l|}{ Inside row } \\
\hline 2 & 175.30 & 58.10 & 22.58 & 7.45 & 1.40 & 0.05 \\
\hline 3 & 137.14 & 45.45 & 17.67 & $\mathbf{5 . 8 3}{ }^{y}$ & 1.09 & 0.04 \\
\hline 4 & 117.13 & 38.82 & 15.09 & 4.98 & 0.93 & 0.03 \\
\hline 5 & 104.05 & 34.48 & 13.40 & 4.42 & 0.83 & 0.03 \\
\hline 6 & 94.59 & 31.35 & 12.19 & 4.02 & 0.75 & 0.03 \\
\hline \multirow[t]{5}{*}{7} & 87.34 & 28.94 & 11.25 & 3.71 & 0.70 & $\mathbf{0 . 0 3}$ \\
\hline & \multicolumn{6}{|c|}{ Avg yield per plot size $(\mathrm{kg})$} \\
\hline & 17.8 & 35.6 & 71.3 & 142.5 & 285.0 & 570.0 \\
\hline & \multicolumn{6}{|c|}{ Plot size (no. of basic units) } \\
\hline & 1 & 2 & 4 & 8 & 16 & 32 \\
\hline \multicolumn{7}{|l|}{ Border row } \\
\hline 2 & 141.92 & 49.35 & 14.08 & $5.01^{y}$ & 1.21 & 0.12 \\
\hline 3 & 111.03 & 38.61 & 11.02 & 3.92 & 0.94 & 0.10 \\
\hline 4 & 94.83 & 32.97 & 9.41 & 3.35 & 0.81 & 0.08 \\
\hline 5 & 84.24 & 29.29 & 8.36 & 2.97 & 0.72 & 0.07 \\
\hline 6 & 76.58 & 26.63 & 7.60 & 2.70 & 0.65 & 0.07 \\
\hline 7 & 70.71 & 24.59 & 7.02 & 2.50 & 0.60 & 0.06 \\
\hline & \multicolumn{6}{|c|}{ Avg yield per plot size ( $\mathrm{kg}$ ) } \\
\hline & 13.2 & 26.3 & 52.7 & 105.3 & 210.6 & 421.2 \\
\hline
\end{tabular}

${ }^{\mathrm{2}}$ Basic unit plot size $=2.23 \mathrm{~m}^{2}$

${ }^{y}$ Values in bold indicate least significant difference values $5 \%$ or less of the average plot yield.

seven would have calculated LSDs less than or equal to $5 \%$ of the mean.

With Hatheway's method to detect a true difference of $20 \%$ or less of the plot yield mean with four replications would take plot sizes of between 10 and 14 basic units and crosses the $20 \%$ threshold at $\approx 11$ basic units with the 2006 inside row data (Fig. 2). Increasing the number of replications to five or above results in plot sizes of less than 10 basic units with $\approx 8$ to 9 basic units required. With two or three replications, the plot sizes are between 10 and 20 basic units with $\approx 13$ basic units with three replications and 16 basic units with two replications.

For the border row, a plot size between 7 and 10 basic units with four replications would be required for a true difference of $20 \%$ of the plot yield mean (Fig. 3). This could also be met with five replications. The approximate size of the plots would be 9 and 8 basic units for replications of four and five, respectively. With two or three replications, plot sizes are between 10 and 14 basic units.

In 2007 with a plot size of $6.69 \mathrm{~m}^{2}$ for the inside row, using Hatheway's method, a plot size of $\approx 3$ basic units and four replications would meet the $20 \%$ threshold (Fig. 4). With two replications it would require a plot size of 4 basic units to meet this threshold.

Because there were more basic units with the border row data in 2007, the trendlines are closer together (Fig. 5). All of the trendlines (two to seven replications) were below $20 \%$ of the plot yield mean with a plot size of 8 basic units or less. For four or five replications, plot sizes of $\approx 5$ basic units would be required to meet the $20 \%$ threshold.

In 2008 with a basic unit of $2.23 \mathrm{~m}^{2}$, regardless of whether it was an inside or border row, all replications with a plot size of 8 basic units or less met the criteria of a true difference of $20 \%$ of the plot yield (Figs. 6 and 7).
Finally, in 2007 and 2008, data were collected on fruit size, soluble solids (\% sugar), and fruit firmness. These data were then plotted with the CV on the $\mathrm{y}$-axis and the plot size in basic units on the $\mathrm{x}$-axis (Fig. 8). The point of maximum curvature for fruit size in 2007 was a plot size of $\approx 6.4$ basic units. In 2008 , this point for fruit size was 5.7 basic units. Soluble solids had this point at 6.8 basic units in 2007 and 4.8 basic units in 2008. For fruit firmness, the most efficient plot size in 2007 was $\approx 7.2$ basic units. The 2008 fruit firmness plot size was $\approx 5.8$ basic units.

Bartlett's test of variance homogeneity in 2006 indicates that plot sizes of 14 to 20 basic units or 14 to 20 plants per plot would be required. This is larger than the common practice of 10 plants per plot. In 2007 with the larger basic unit, plot size would require eight to 16 plants per plot. The 2008 results with a smaller basic unit size suggest 10 to 21 plants per plot. Because the basic unit size is smaller than the plant in-row spacing suggests, these results may be suspect. The 2006 and 2007 tests suggest that experiments with more plants per plot may result in more reliable detection of differences between treatments.

The computed LSD values in 2006 offer some interesting alternatives to current practices of 10 plants per plot and four replications. With a $1.83-\mathrm{m}$ in-row spacing, computed LSDS indicate that 14 or 20 plants with two replications would meet the 5\% threshold and would involve fewer plots per treatment with an inside row. Either three or four replications for inside row plots would require plots of 14 plants. Results were similar for the border row plots. This suggests that having designated border rows would not be necessary. In 2007 with larger basic unit plots $\left(6.69 \mathrm{~m}^{2}\right)$, the number of plants required per plot with a 6 basic unit plot size and four replications would be 12 plants per plot. This results in 48 


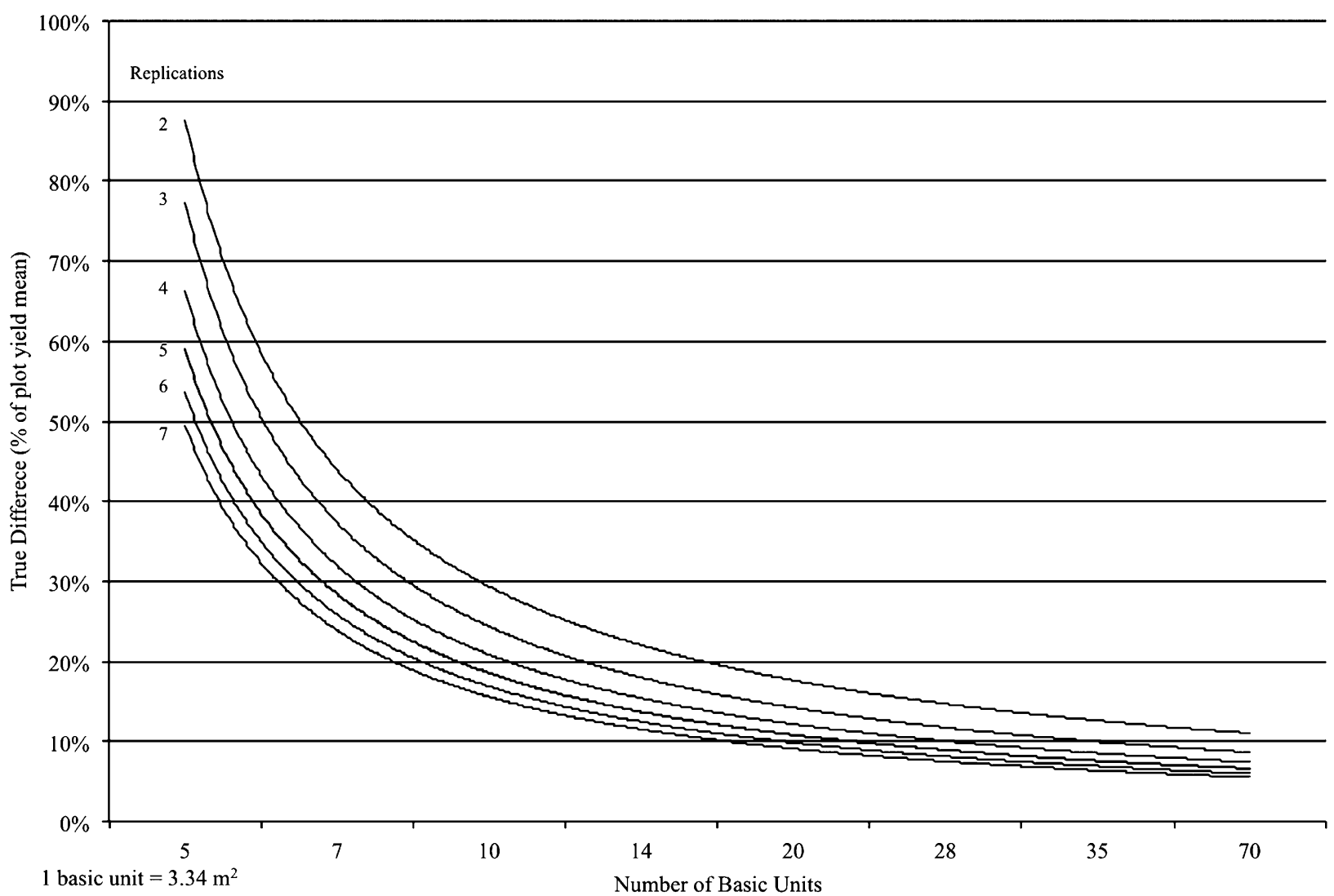

Fig. 2. Power trendlines of Hatheway's method to detect true yield differences as a percent of the mean based on number of basic units (inside row, 2006).

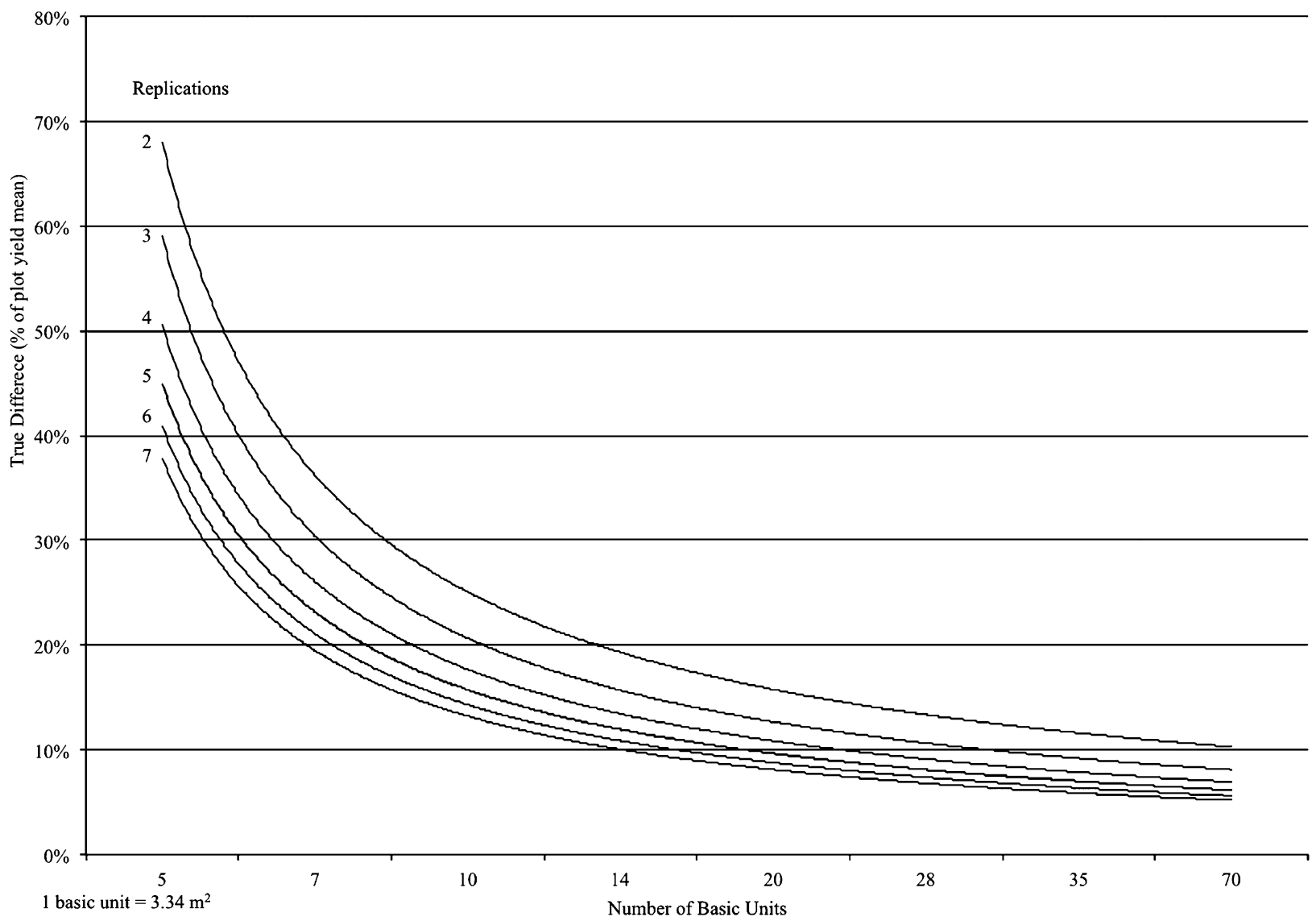

Fig. 3. Power trendlines of Hatheway's method to detect true yield differences as a percent of the mean based on number of basic units (outside row, 2006). 


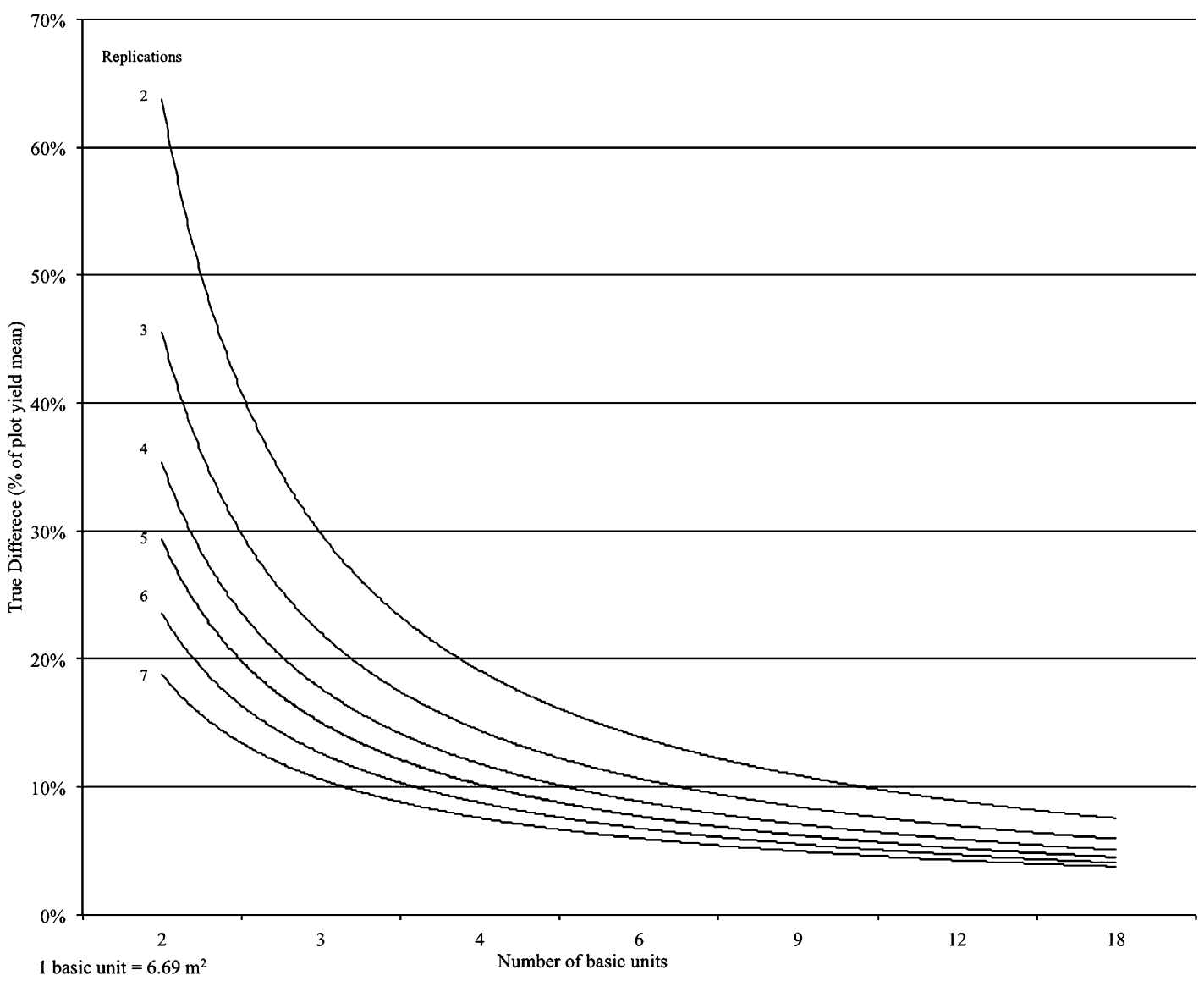

Fig. 4. Power trendlines of Hatheway's method to detect true yield differences as a percent of the mean based on number of basic units (inside row, 2007).

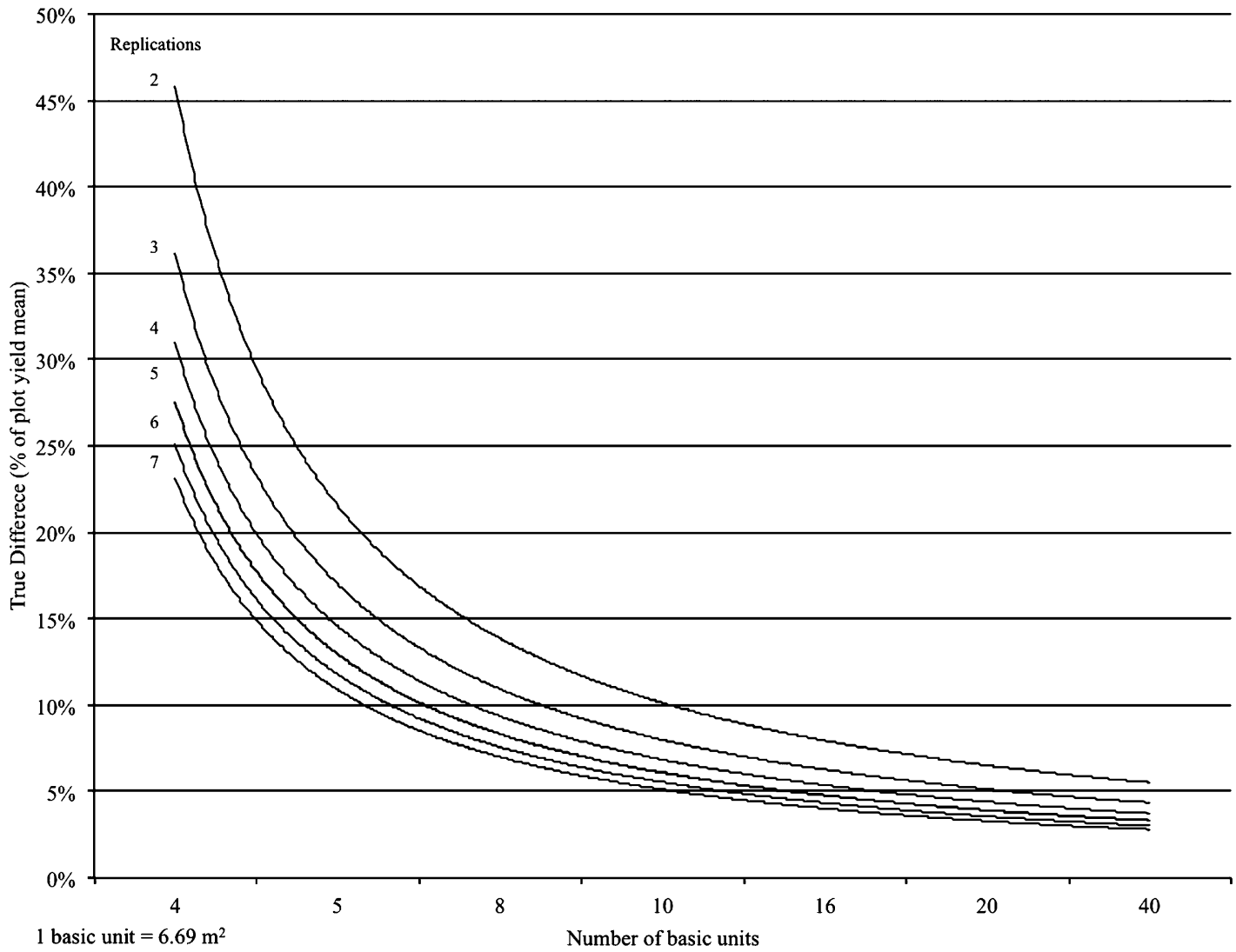

Fig. 5. Power trendlines of Hatheway's method to detect true yield differences as a percent of the mean based on number of basic units (outside row, 2007). 


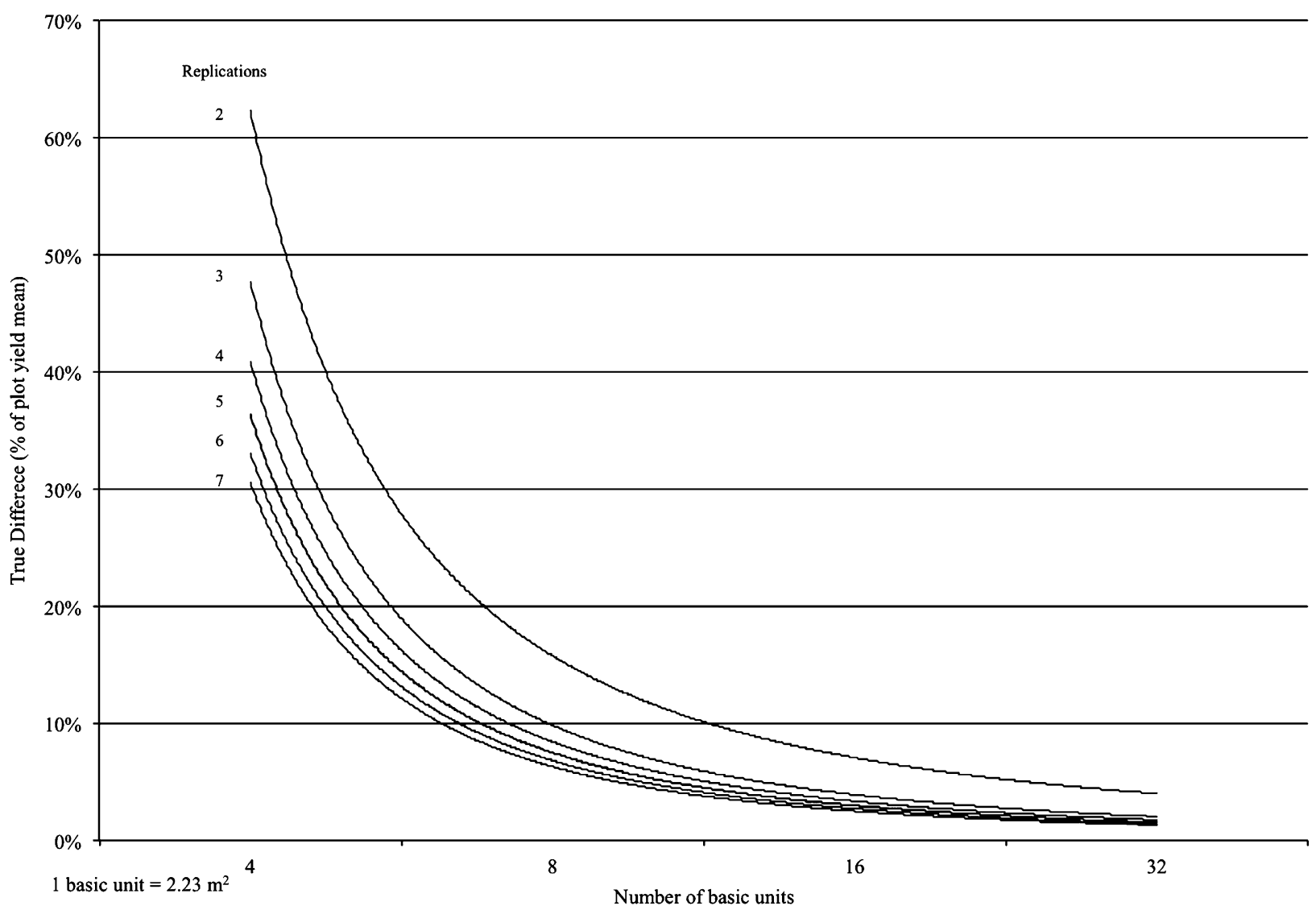

Fig. 6. Power trendlines of Hatheway's method to detect true yield differences as a percent of the mean based on number of basic units (inside row, 2008).

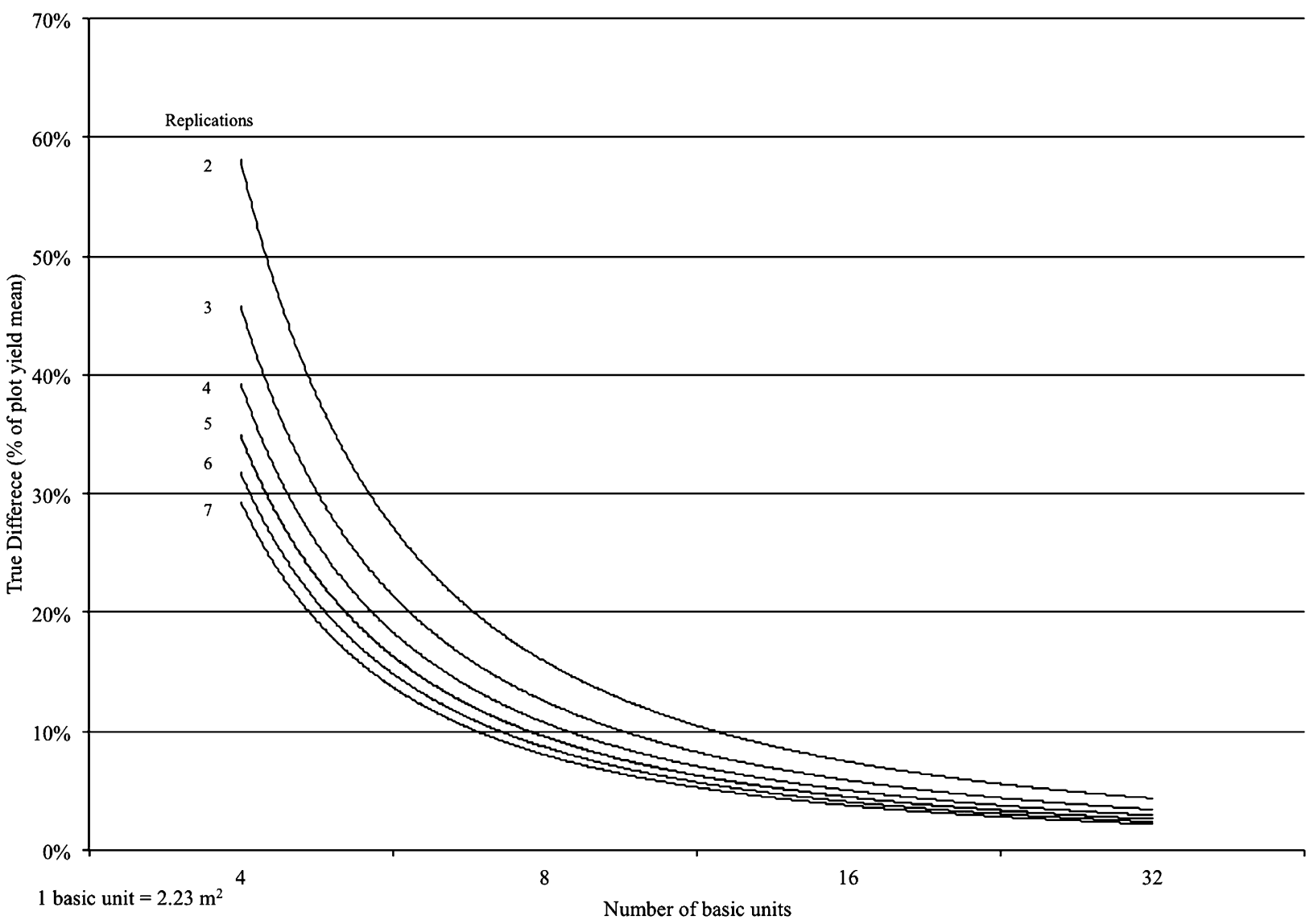

Fig. 7. Power trendlines of Hatheway's method to detect true yield differences as a percent of the mean based on number of basic units (outside row, 2008). 


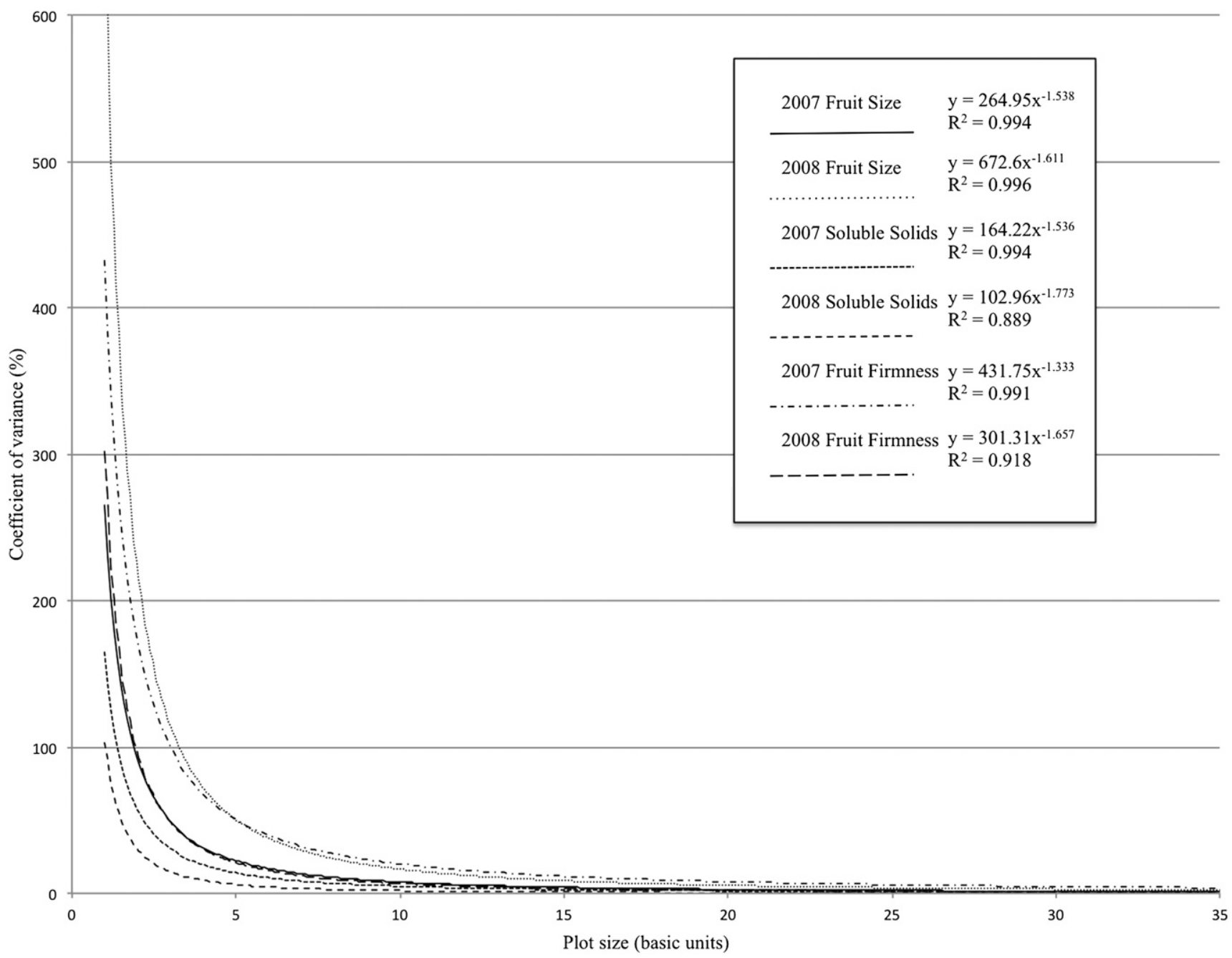

Fig. 8. Power trendlines of $\mathrm{cv}$ against plot sizes for fruit size, soluble solids, and fruit firmness with basic unit plot sizes of $6.69 \mathrm{~m}^{2}$ for 2007 and $2.23 \mathrm{~m}^{2}$ for 2008 .

plants per treatment for inside rows. The border rows in 2007 met the $5 \%$ criteria with a plot size of 8 basic units and two replications. This would result in 16 plants per plot and a total of 32 plants per treatment. For three and four replications, the plot size would be the same for border rows in 2007. In 2008 , the plot size was smaller $\left(2.23 \mathrm{~m}^{2}\right)$ and inside row LSD values met the $5 \%$ criteria with 8 basic unit plot size and three replications. This would result in plots of six plants and 18 plants per treatment. With the border row, the 5\% criteria could be met with an 8 basic unit plot size and two replications or 12 plants per treatment. Overall the size of the starting basic unit appears to have considerable influence over the results. Because the 2008 in-row plot size is smaller than the in-row plant spacing, this may have reduced the reliability of these results. The 2006 and 2007 results suggest that more plants per plot (12 to 16) might result in detecting differences more reliably.

The somewhat larger plot size with the 2006 data based on the point where a tangent line has a slope of -1 for the $\mathrm{CV}$ against the plot size (Fig. 1) is to be expected because there were several different varieties involved in this sample. This is probably a more realistic estimate of plot size for variety trials where several different melon types would be grown. The point where a tangent line has a slope of -1 where a single variety was used required fewer basic units per plot. This may also be influenced by the different size of the basic units.

The same approach of plotting the $\mathrm{CV}$ against the number of basic units was used with the fruit size, soluble solids, and firmness. Whether plotting for yield or fruit characteristics, because of the different units used on the y-axis (CV) vs. the x-axis (basic units), to calculate the point of maximum curvature $(-1)$, the $\mathrm{x}$ - and $y$-axis scales had to be adjusted so that the same units were used on both. This was required to calculate an accurate point of maximum curvature. To do this, both scales were adjusted to 100 and this was then used to calculate the number of basic units required for each. Because of this, the points on the graph may appear inaccurate compared with the numbers reported in the text. In any case, the number of basic units calculated may give a false impression of greater precision than actually exists in the data collected.

Using Bartlett's test attempts to identify the plot size where the variance per unit area does not change even when larger plot sizes are used. The variance per unit area evaluation in 2006 suggests that a plot size of 20 basic units or a plot size of $66.8 \mathrm{~m}^{2}$ for the inside row should be used. The border row on the other hand indicates 14 basic units or a plot size of $46.8 \mathrm{~m}^{2}$. This is somewhat counterintuitive in that it would be expected that the inside row would be more uniform and thus result in a smaller plot size. Because this did not occur, it may be evidence that border rows around an experimental field are not necessary. In 2007 with a basic unit size of $6.69 \mathrm{~m}^{2}$, the minimum size for inside plots was 4 basic units or $26.8 \mathrm{~m}^{2}$ plots and 8 basic units or $53.5 \mathrm{~m}^{2}$ for border row plots. In 2008, with a basic unit of $2.23 \mathrm{~m}^{2}$, there was no clearcut point to select a plot size with Bartlett's test because all plot sizes for inside rows were significantly different from each other and only the 16 and 32 basic unit plot sizes differed from each other for the border rows (Table 3). Because the length of a basic unit $(1.22 \mathrm{~m})$ in 2008 was less than the in-row planting distance $(1.83 \mathrm{~m})$, it may have reduced the effectiveness of this analysis method.

In conclusion, these results suggest that smaller plot sizes could be used particularly where experiments involve a single variety or when resources are limited. This may have particular benefit for plant breeders specifically early in their breeding efforts when a large 
number of lines have to be evaluated. In addition, the use of border rows around experiments may be unwarranted because the performance of border rows and inside rows were similar regardless of the type of analysis. However, more research in this area, particularly comparing similar plot sizes over more than 1 year, might be warranted.

\section{Literature Cited}

Bhatnagar, S., O.P. Srivastava, and B.P.S. Lather. 1991. Optimum size and shape of plot for mustard. Annals of Agricultural Research 12:72-78.

Boyhan, G.E. and W.T. Kelley. 2000. Commercial watermelon production. Univ. of Ga. Coop. Ext. Serv. Bul. 996.

Boyhan, G.E., D.B. Langston, A.C. Purvis, and C.R. Hill. 2003. Optimum plot size and number of replications with short-day onions for yield, seedstem formation, number of doubles, and incidence of foliar diseases. J. Amer. Soc. Hort. Sci. 128:409-424.
Gomez, K.A. and A.A. Gomez. 1984. Statistical procedures for agricultural research. 2. John Wiley \& Sons, New York, NY.

Hatheway, W.H. 1961. Convenient plot size. Agron. J. 53:279-280.

Lana, E.P., P.G. Homeyer, and E.S. Haber. 1953. Field plot techniques in vegetable crops. Proceedings. American Society for Horticultural Science 62:21-30.

Locascio, S.J., F.G. Martin, and H.W. Lundy. 1966 Plot size studies with watermelons. Proceedings. American Society for Horticultural Science 89:597-600.

Neppl, G.P. and T.C. Wehner, Series Editor. 2001. Survey of watermelon trialing methods used by breeders in the United States, Cucurbit Genetics Cooperative. Cucurbit Genetics Cooperative, College Park, MD.

Parlak, N. and A. Kircalioglu. 1979. Optimum plot size and shape, and number of replications for tomato, capsicum and eggplant experiments. Domates (Lycopersicum esculentum Mill.), biber (Capsicum annum L.) ve patlican (Solanum melongena L.) denemeleri icin en uygun parsel buyukluk, bicim ve yineleme sayisinin saptanmasi. Tarimsal Arastirma Dergisi 1:101-107.

Pecina, M. 1993. Optimum plot size and shape in tests with hybrids of maize (Zea mays L.) of different maturity groups. Optimalna veličina i oblik osnovne parcele u pokusima s hibridima kukuruza (Zea mays L.) različitih vegetacijskih grupa. Poljoprivredna Znanstvena Smotra 58:197-213.

Pemajayantha, V. and A.L. Gunasekara. 1982. A study on the optimum plot size for potato experiments. Tropical Agriculturist 45-57.

Rampton, H.H. and R.G. Petersen. 1962. Relative efficiency of plot size and numbers of replications as indicated by yields or orchard grass seed in a uniformity test. Agron. J. 54:247-249.

Singh, R.P. 1989. Optimum plot size for yield trials on chillies. Indian Journal of Horticulture 46:404 406.

USDA. 2011. Economics, statistics, and market information system. 15 Oct. 2012. <http://usda. mannlib.cornell.edu/MannUsda/viewDocumentInfo. do?documentID $=1399 \% 3 \mathrm{E}>$

Vallejo, R.L. and H.A. Mendoza. 1992. Plot technique studies on sweetpotato yield trials. J. Amer. Soc. Hort. Sci. 117:508-511. 